\title{
Students' leisure consumption patterns in cities: Three-dimensional pictures from Lodz and Turin
}

\begin{abstract}
The research conducted relates to university students' leisure practices in urban settings. A three-dimensional framework to picture and analyse students' leisure, focusing on its temporal, economic and spatial dimensions, is proposed. The analysis is based on empirical evidence from two European cities, namely Lodz, Poland and Turin, Italy. First, the findings show that students' leisure consumption goes beyond visiting music and disco clubs, and it is oriented towards meeting at home, visiting pubs and cafés, and also shopping for non-daily products. Secondly, the geographies of the majority of students' leisure activities do not spatially overlap with the places of their education and accommodation. Thirdly, the data obtained on students' leisure consumption in Lodz and Turin reveal many similarities, despite the contextual differences between the two cities.
\end{abstract}

Keywords

University students $\cdot$ student city $\cdot$ leisure economy $\bullet$ consumption

(C) University of Warsaw - Faculty of Geography and Regional Studies
Jakub Zasina

Department of Regional Economics and Environment Institute of Spatial Economics, Faculty of Economics and Sociology, University of Lodz, Lodz, Poland e-mail: jakub.zasina@uni.lodz.pl

Received: 6 May 2020

Accepted: 7 July 2020
Introduction

The rising culture of consumerism has started to manifest itself spectacularly, mostly in urban settings (Jayne 2006). Cities have been transforming into nodes of leisure consumption to meet the needs and whims of consumer society (Clark 2011). Some cities have implemented policies to develop the leisure economy, and the night-time economy in particular, which is also seen as a step towards economic restructuring (Bromley, Tallon \& Thomas 2003; Brands, Schwanen \& van Aalst 2014; Crivello 2011). Young adults, among them university students, constitute an important part of the new generation of consumption-oriented urbanites.

In line with the rise of the post-Fordist and knowledgebased economy, higher education has expanded substantially. This trend is visible in the rising number of Higher Education Institutions (HEIs) and student enrolments. Public policies have promoted the education of young professionals (Munro \& Livingston 2012; Hauschildt et al. 2015) to foster the advantages of states, regions and cities that are now competing in 'the development game' of the 'new economy'. As a result of the massification of higher education, cities worldwide have experienced an influx of young people looking for education opportunities. Moreover, student populations have grown not only in historical university towns but also in cities with different pasts, for example former manufacturing centres (Wattis 2013).

The current research focuses on the intersection of two essential processes in post-industrial urban restructuring, namely the rise of consumerism and the growth of higher education enrolments, which is taking place in many contemporary cities that host university students. Although students have been present in towns and cities for decades if not centuries, recently they have gained more attention from scholars (Kotus, Rzeszewski \& Bajerski 2018). As communities hosting HEls have been fuelled by a ' $[. .$. lucrative, sizable, and dependable consumer population [...]' of students, they have mutated into 'consumption-oriented student cities' (Chatterton 2010) within the broader framework of neoliberal urban change and commodification. 'Studentscapes' have sprawled through cities, although in different forms (Russo \& Tajter 2007), creating student areas that offer private accommodation to let (Smith 2005), and/or bars, pubs, cafés, clubs and other venues to visit (Chatterton 1999). Some cities associate the growth of the student population with positive changes (Sokołowicz 2019), while others have experienced its negative externalities (Allinson 2006; Munro \& Livingston 2012)

Although the numerous ways students have impacted cities worldwide have generated volumes of papers, research remains oriented towards student accommodation issues (Nakazawa 2017), focusing on single, usually Anglo-Saxon, case studies (Moos et al. 2019), and neglecting other topics and locations. Hence, this paper analyses student leisure consumption and discusses its role for urban economies and geographies using original survey data gathered among student populations in two European cities, namely Lodz, Poland and Turin, Italy. Moreover, it presents and employs a conceptual framework for studying university students' leisure consumption patterns in a three-dimensional approach that is, in temporal, economic and spatial dimensions.

The paper begins with a review of the literature devoted to higher education students and their leisure consumption. This section is followed by an overview of the applied methodology and a brief description of the two cities chosen for the comparative 
study. Next, the paper explores and compares three-dimensional pictures of students' leisure activities in Lodz and Turin. Finally, it discusses the role of students' leisure consumption patterns for their host cities.

University students and the leisure economy in contemporary cities

Students have been users of university towns and cities for centuries. From an economic point of view, their presence used to be associated with an accelerated exogenous demand for goods and services produced locally (Brockliss 2000). Nevertheless, student populations remained at the peripheries of urban studies scholarship until the end of the 1990s. The limited research on students in cities seemed to be part of a broader issue, namely the negligence of research into young people in urban environments (Skelton \& Gough 2013). However, due to the expansion of higher education, students are now a substantial population in many cities worldwide and a visible group of consumers. Therefore, they have gained special attention from researchers in recent years (Kotus, Rzeszewski \& Bajerski 2018).

The current academic debate sheds light on higher education and consumption as engines of ongoing urban change. In that context, some scholars have highlighted the phenomenon of leisure economy growth in university cities, which is related to the rising population of students. Young people's preference to gather and socialise in bars, pubs, cafés and clubs in university cities creates pressure to establish and develop the 'student urban service sector' (Chatterton 2010), which comprises businesses serving the academic youth

Students have been characterised as frequent visitors of pubs and clubs (Brands, Schwanen \& van Aalst 2014), especially middle- and upper-class 'traditional' students in their first year of university enrolment (Chatterton 1999; Christie, Munro \& Rettig 2001). However, more recent studies show that the student model of leisure is changing. Gant \& Terry (2017) highlight a shift among British students from the 'pub-club' to 'home-pub-club' pattern of night-time consumption, with connotations of 'pre-loading'. Moreover, Polish researchers point out that meeting friends and organising a party at home instead of going out is one of the economising strategies that are popular among students due to the limits of their budgets (Grabkowska \& Frankowski 2016).

Considering the frequency of consumer activities, students are perceived as going out more frequently than the rest of the urban population (Hollands 1995; Brands, Schwanen \& van Aalst 2014). However, their presence in the city, and therefore their leisure consumption patterns, is partly dependent on the broader temporal frameworks constituted by HEls (Chatterton 1999). Thus, on some days or in some months, university cities experience a temporal shrinkage of student populations (Dubet 2006), making the operation of local student-oriented businesses fluctuate (Garmendia, Coronado \& Ureña 2012; Ackermann \& Visser 2016).

The vivid worldwide debate on intra-urban student geographies originated in the UK, where certain neighbourhoods in university cities and towns have been 'studentified' due to the off-campus accommodation boom. According to the seminal work by Smith (2005), urban neighbourhoods that are studentifying face various impacts, among them the emergence of leisure venues oriented towards students. In some cases, studentification has led to the rise of specific consumption venues (Fabula et al. 2017), while in others, it has resulted in the erosion of infrastructure tied to the needs and tastes of non-students (Sage, Smith \& Hubbard 2012). The rise of the 'student city' is also spatially reflected in urban areas devoted to hosting student-oriented leisure venues. Such areas, which Chatterton \& Hollands (2002) refer to as 'playscapes', tend to concentrate 'young people's activities in bars, pubs, night clubs and music venues within the night-time entertainment economy.' The concentration of these businesses in particular places can be useful from the students' point of view, as it increases the chance of meeting people of a similar age and lifestyle (Chatterton 1999). However, in some cities, areas of students' night-time consumption are spatially separated from the places of their accommodation. For instance, venues catering to students often operate in city centres (Murzyn-Kupisz \& Szmytkowska 2015; Calvo 2017; Gant \& Terry 2017) or along major streets next to an HEl's facilities (Chatterton 2010).

Students' consumption patterns in cities have been studied by researchers from different academic fields, but they are of special interest to geographers and economists. Geographers add novel conceptualisations and knowledge to the spatial and temporal patterns of university students' presence in and impacts on cities, such as 'studentification' (Smith 2005; Smith \& Holt 2007; Sage, Smith \& Hubbard 2012; Smith \& Hubbard 2014; Nakazawa 2017) and 'studentscapes' (Russo \& Tajter 2007). They also provide numerous insights into the physical, temporal, social and cultural aspects of the leisure consumption of higher education students (Hollands 1995; Chatterton 1999; Smith 2005; Calvo 2017; Fabula et al. 2017; Gant \& Terry 2017). By contrast, economists measure students' expenditures (e.g. Gaczek \& Kaczmarek 2015; Hermannsson, McGregor \& Swales 2018), often as part of studies on the economic impact of HEls. However, with the exception of Steinacker (2005), their findings do not usually provide insights into the intra-urban distribution of this expenditure. On the whole, the ongoing multidisciplinary debate over students' presence in cities seems to exclude the linkage between the spatial and economic dimensions of their leisure. Furthermore, the focus on single case studies and night-time practices in the research into student consumption limits the current understanding of student leisure. Thus, we should research different modes of student leisure, in a way that enables a comparative analysis of data from various university cities.

\section{Methodology}

The exploration of urban phenomena through comparative research is an emerging trend because, in the globalised world, it helps us to broaden the view resulting from single case studies. However, it has not yet gained much attention among scholars dealing with student populations in cities. Following this reasoning, this contribution aims to capture, describe, and compare leisure consumption patterns of higher education students using a threedimensional approach and employing empirical evidence of student populations in two European cities, namely Lodz (Łódź) and Turin (Torino). Although these two cities function in different historical, economic, socio-cultural and geographical contexts, they share two crucial phenomena of the ongoing global urban restructuring, namely substantial deindustrialisation and the remarkable growth of the higher education sector. This makes them an appropriate choice for a comparative study formula (Robinson 2017).

Lodz, the third-largest city in Poland, had a population of 696,503 people in 2017 (Statistics Poland 2018), while Turin, with 884,733 inhabitants, was ranked the fourth most populous city in Italy in the same year (Città di Torino 2018). Therefore, in relation to population size, as well as their role in the European settlement system, they can be labelled 'second-tier' cities. Moreover, both cities were economically dominated by one type of manufacturing for decades. More specifically, Lodz was the centre of the Polish textile and clothing industry from the 19th century (Zasina, Sokołowicz \& Nogalski 2020), while in the 20th century, Turin was a leading European example of a 'motor city' (Caruso, Pede \& Rossignolo 2019). The loss of industrial production in the 1980s and 1990s led both cities towards economic decline and population shrinkage. However, it also started a long-term process of urban reinvention (Gałuszka 2017; Ponzini \& Santangelo 2018). 
Table 1. Sample characteristics

\begin{tabular}{|c|c|c|}
\hline & Lodz & Turin \\
\hline Sample size & 1059 & 1042 \\
\hline Students by Higher Education Institution (HEI)* & $\begin{array}{c}\text { 54.4\% UŁ (university) } \\
24.4 \% \text { P } \text { (technical university) } \\
16.2 \% \text { UM (medical university) } \\
\text { 1.9\% ASP (art school) } \\
\text { 1.7\% AM (music school) } \\
\text { 1.4\% PWSFTviT (film school) }\end{array}$ & $\begin{array}{c}61.1 \% \text { UT (university) } \\
37.5 \% \text { PT (technical university) } \\
1.5 \% \text { AA (music school) }\end{array}$ \\
\hline Students by level of education* & $\begin{array}{c}55.6 \% \text { undergraduate } \\
44.4 \% \text { graduate }\end{array}$ & $\begin{array}{c}66.9 \% \text { undergraduate } \\
33.1 \% \text { graduate }\end{array}$ \\
\hline $\begin{array}{c}\text { Students by domicile } \\
\text { Local - students living in the city before entering HEI } \\
\text { Non-local - students not living in the city before } \\
\text { entering HEl }\end{array}$ & $\begin{array}{c}33.8 \% \text { local } \\
66.2 \% \text { non-local }\end{array}$ & $\begin{array}{c}24.0 \% \text { local } \\
76.0 \% \text { non-local }\end{array}$ \\
\hline $\begin{array}{c}\text { Students by residence } \\
\text { Residents - students living in the city permanently or } \\
\text { temporarily } \\
\text { Commuters - students commuting to the city }\end{array}$ & $\begin{array}{l}76.8 \% \text { residents } \\
23.2 \% \text { commuters }\end{array}$ & $\begin{array}{l}72.9 \% \text { residents } \\
27.1 \% \text { commuters }\end{array}$ \\
\hline
\end{tabular}

* Variables controlled in the sampling procedure.

Source: own elaboration.

Lodz and Turin have experienced remarkable growth in higher education in recent decades. It could be said that higher education has become a new 'industry' for these two former manufacturing cities (Mangione 2019; Sokołowicz 2019). Nowadays, they host a substantial number of students, namely 50,299 fulltime students enrolled in public HEls in Lodz in 2017 (Statistics Poland 2018) and 93,836 in Turin (OSSREG 2017). Turin has been home to a student community for several centuries as its university was established in the 15th century. By contrast, HEls in Lodz were launched mostly in the 1940s due to the post-war, socialist modernisation of the city (Zysiak 2016). The Lodz student population boomed during Poland's transition from socialism to capitalism (Zasina, Sokołowicz \& Nogalski 2020), following the pattern of other post-socialist cities (Fabula et al. 2017). Since the 1990s, both cities have developed HEls as a solution for socio-economic and spatial redevelopment. However, while in Turin the growth of higher education was a goal set in numerous municipal policy instruments (Mangione 2019), in Lodz it was rather an organic and 'entrepreneurial' response to the educational boom by the local HEls. Furthermore, although the development of higher education infrastructure has substantially transformed Lodz and Turin cityscapes in recent decades, HEI facilities tend to be clustered on the edges of their central zones in both cities, taking the form of campuses or semi-campuses (Zasina 2020).

To meet the requirements of an international study (Daniłowicz 2007), and to take complex, but comparable, pictures of students' leisure in particular, the research followed the standardised, quantitative study formula in both cities, focusing on the frequency of students' leisure activities (temporal dimension), related expenditure (economic dimension) and the urban areas visited (spatial dimension). More specifically, students were asked to delineate their leisure activities spent in music and night clubs, pubs and cafés, and cultural and sports venues, but also in places of non-daily shopping (e.g. for clothing, electronics), and when meeting friends at 'home' (the place of temporary or permanent residence) as a guest or a host. The students were instructed to limit their answers to activities that occurred only during term-time in each city. They were asked to assess the frequency and geography of their activities by choosing one of the four pre-defined answers for each activity type. At the same time, they freely provided monetary amounts in their national currencies when answering the question about expenditure. To make the results reliable, only those students who declared that they regularly undertook the types of activities examined were asked to provide details of the expenses and geographies (including the names of preferred venues).

The pilot-tested survey was administered between March 2017 and February 2018 as part of wider research on the impact of university students on Lodz and Turin. To ensure the comparability of the two datasets, the same sampling procedure was applied to survey students enrolled in all public HEls in both cities: 6 HEls in Lodz and 3 HEls in Turin. The sample reflects the student population structure through the control of two variables, namely how students are assigned to HEls and their units (departments), and their level of education (Table 1). In brief, the survey was designed to cover a representative group of students from different education fields, lifestyles, and everyday geographies. Individual paper questionnaires were administered directly by interviewers among Polish and Italian full-time students at HEls facilities spread around Lodz and Turin. International students were purposely omitted, as they seem to have unique consumption practices (Collins 2010; Calvo, Nofre \& Geraldes 2017). Following this reasoning, PhD students were also excluded in the sampling procedure because of their different life courses and socio-economic status (Ruming \& Dowling 2017). Ultimately, a total of 1,059 university students in Lodz and 1,042 in Turin completed the questionnaires correctly and were included in the sample.

Table 1 shows the proportion of students from each HEI included in the database, which matched the number of students who were enrolled in the HEls in both cities (by departments in the institutions; departments are not detailed in the table). Moreover, in line with the structure of full-time students enrolled in these HEls, more of them were undergraduate students $(55.6 \%$ 


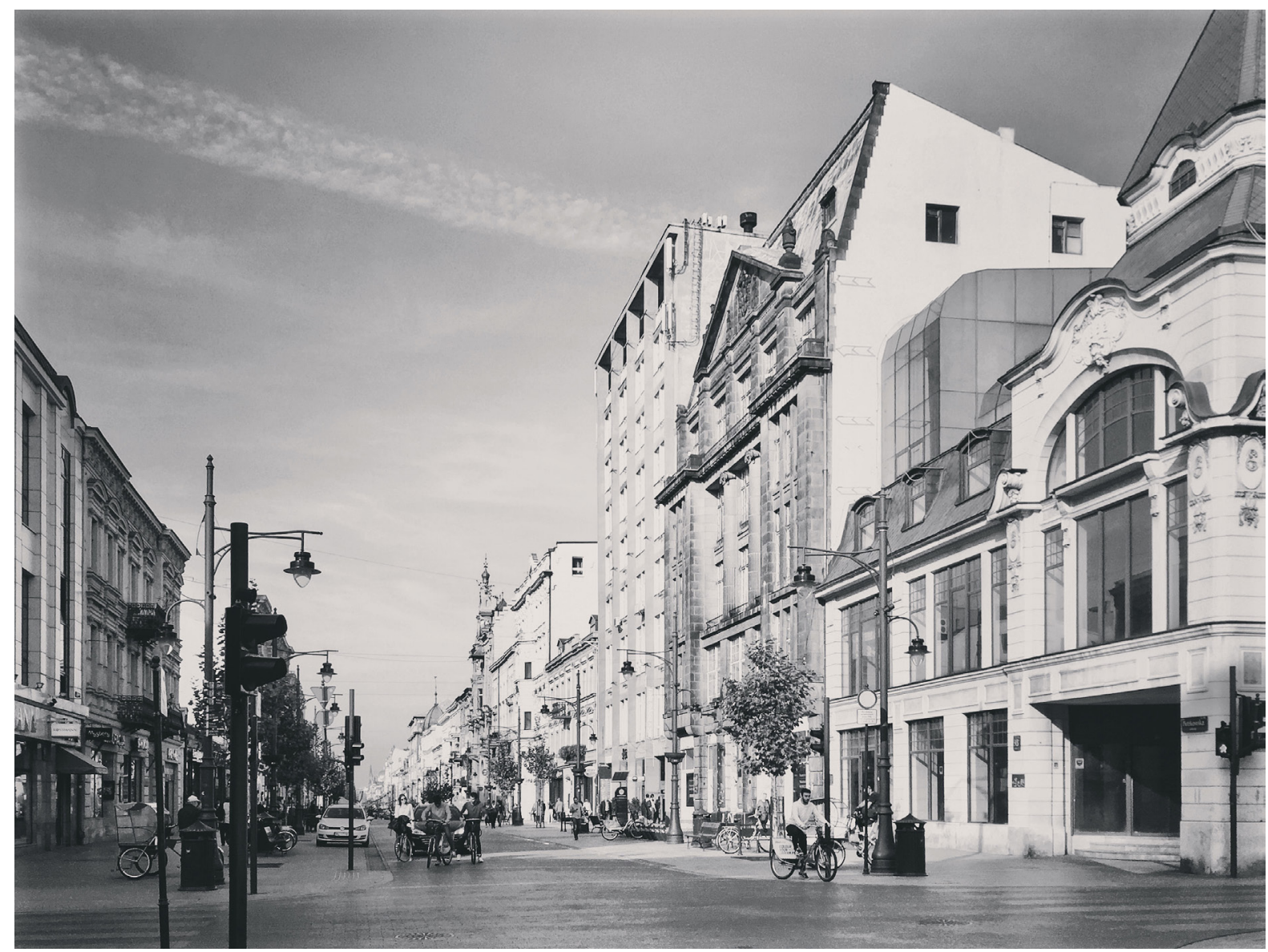

Figure 1. Ulica Piotrkowska in Lodz Source: Jakub Zasina (2017).

in Lodz and $66.9 \%$ in Turin) than graduate students $(44.4 \%$ and $33.1 \%$, respectively). The study covered more non-local $(66.2 \%$ and $76.0 \%$, respectively) than local students $(33.8 \%$ and $24.0 \%$, respectively). Similar shares of students reside in Lodz and Turin permanently or temporarily $(76.8 \%$ in Lodz and $72.9 \%$ in Turin) and commute to these two cities daily $(23.2 \%$ and $27.1 \%$, respectively).

Three-dimensional pictures of students' leisure consumption from Lodz and Turin

\section{Students' leisure in Lodz: a preference for shopping}

The results show that the most common type of leisure activity among students in Lodz is meeting friends at home (at their place of permanent or temporary residence). In total, $89.2 \%$ of Lodz students declared that they visited or hosted friends regularly. Students in Lodz spend EUR 12.95 per month on such activities on average, and this expenditure is associated with the consumption of food and beverages.

However, apart from meeting friends at home, the single most common leisure activity of the youth studying in Lodz is nondaily shopping (e.g. for clothing or electronics). In total, $85.2 \%$ of them report regularly visiting venues for non-daily shopping, and $32.4 \%$ visit them at least once per week. Therefore, it seems that for Lodz students, shopping is a basic form of leisure. Among the activities studied, non-daily shopping is also the costliest. Students report an average expenditure of EUR 40.35 per month on purchasing clothes, electronics and other non-daily products, usually in large shopping centres located on the edges of the city centre.

Visiting pubs and cafés features among the common leisure activities of Lodz students, as $75.9 \%$ of the respondents stated that they regularly visit venues of this type. Lodz students spend an average of EUR 14.85 per month there. The area of the city that benefits economically from this expenditure is predominantly Ulica Piotrkowska (Piotrkowska Street, Figure 1), a historical and commercial street, which is the central axis of the city.

A relatively common type of leisure activity among students in Lodz is visiting cultural venues, with approximately $57 \%$ of students saying they visit a cultural attraction regularly. However, it is not the most regular type of activity, as roughly $6 \%$ of the students declared that they visit such places at least once per week. On average, students in Lodz spend EUR 9.98 per month enjoying culture out of the home, but this is limited to watching films in multiplexes that operate in the centre of Lodz.

Although practising regular sports activities is quite costly (EUR 14.21 per month on average), $52.1 \%$ of the students visit sports venues regularly, mostly in the neighbourhoods where they live. However, while $26.3 \%$ of the student population of the city declare that they visit gyms, fitness clubs, swimming pools and sports clubs 'very frequently', an even larger proportion $(47.9 \%)$ state that they visit them rarely or not at all.

Students enrolled in HEls in Lodz are not frequent visitors to music and night clubs. Only $37.9 \%$ of students said they regularly visit these types of night-time venues, making this activity the least frequent of those studied. Having fun in such clubs is not 
Table 2. Frequency of students' leisure activities

\begin{tabular}{|c|c|c|c|c|c|c|c|c|c|c|}
\hline \multirow[b]{4}{*}{ Activity } & \multicolumn{5}{|c|}{ Lodz } & \multicolumn{5}{|c|}{ Turin } \\
\hline & \multirow[b]{3}{*}{$n$} & \multicolumn{4}{|c|}{ Frequency } & \multirow[b]{3}{*}{ n } & \multicolumn{4}{|c|}{ Frequency } \\
\hline & & \multicolumn{3}{|c|}{ Regularly } & \multirow[b]{2}{*}{$\begin{array}{c}\text { Less often } \\
\text { (occasionally) } \\
\text { or not at all \% }\end{array}$} & & \multicolumn{3}{|c|}{ Regularly } & \multirow[b]{2}{*}{$\begin{array}{c}\text { Less often } \\
\text { (occasionally) } \\
\text { or not at all \% }\end{array}$} \\
\hline & & $\begin{array}{c}\text { At least } \\
\text { once } \\
\text { per } \\
\text { week } \%\end{array}$ & $\begin{array}{c}\text { At least } \\
\text { once } \\
\text { every } \\
\text { two } \\
\text { weeks \% }\end{array}$ & $\begin{array}{c}\text { At least } \\
\text { once per } \\
\text { month \% }\end{array}$ & & & $\begin{array}{c}\text { At least } \\
\text { once } \\
\text { per } \\
\text { week } \%\end{array}$ & $\begin{array}{l}\text { At least } \\
\text { once } \\
\text { every two } \\
\text { weeks \% }\end{array}$ & $\begin{array}{c}\text { At least } \\
\text { once per } \\
\text { month \% }\end{array}$ & \\
\hline $\begin{array}{c}\text { Visiting } \\
\text { music \& } \\
\text { night clubs }\end{array}$ & 1059 & 6.6 & 8.5 & 22.8 & 62.1 & 1028 & 5.6 & 14.0 & 22.1 & 58.3 \\
\hline $\begin{array}{l}\text { Visiting } \\
\text { pubs and } \\
\text { cafés }\end{array}$ & 1059 & 17.8 & 20.9 & 37.2 & 24.1 & 1030 & 37.5 & 24.4 & 21.4 & 16.7 \\
\hline $\begin{array}{l}\text { Visiting } \\
\text { cultural } \\
\text { venues }\end{array}$ & 1058 & 6.3 & 11.9 & 39.2 & 42.6 & 1032 & 6.8 & 18.9 & 39.4 & 34.9 \\
\hline $\begin{array}{l}\text { Visiting } \\
\text { sports } \\
\text { venues }\end{array}$ & 1059 & 26.3 & 9.4 & 16.4 & 47.9 & 1029 & 35.5 & 6.2 & 6.5 & 51.8 \\
\hline $\begin{array}{c}\text { Doing } \\
\text { non-daily } \\
\text { shopping } \\
\text { (e.g. clothing, } \\
\text { electronics) }\end{array}$ & 1059 & 32.4 & 19.0 & 33.8 & 14.8 & 1029 & 4.2 & 15.0 & 42.0 & 38.8 \\
\hline $\begin{array}{c}\text { Meeting } \\
\text { friends at } \\
\text { home* } \\
\text { (as a guest or } \\
\text { a host) }\end{array}$ & 1059 & 41.7 & 26.6 & 20.9 & 10.8 & 1029 & 43.7 & 22.9 & 19.0 & 14.4 \\
\hline
\end{tabular}

* 'Home' means place of permanent or temporary residence.

Source: own elaboration.

merely occasional, it is also expensive, since students who prefer this type of leisure activity spend EUR 16.87 per month on them on average. The clubs that are popular among students are clustered mostly in Lodz's central areas, namely Ulica Piotrkowska, and the surrounding blocks.

Students' leisure in Turin: pubs and cafés like second homes

In Turin, meeting friends at home is the most prevalent leisure activity among students, with $85.6 \%$ of them visiting or hosting friends regularly. Socialising at home does not require high expenditure, as Turin students report average monthly expenses of only EUR 9.76 for that activity, while the median value is actually EUR 0.00 . When having get-togethers at home, students probably consume products purchased for individual or household use, which may not be treated as expenditure dedicated to meetings of this kind.

Visiting pubs and cafés is also a popular leisure-type activity among students in Turin. Over $83 \%$ of them report visiting these venues regularly in their leisure time, and $37.5 \%$ of the student population visit them at least once per week or more often. Thus, socialising in pubs and cafés determines the picture of students' out-of-home leisure in the city. This suggests that such venues might be treated as a sort of 'second home' for students (or their 'third places', in reference to the concept of Oldenburg, 1999). These venues operate mostly in an area within walking distance of Via Roma (Rome Street) and in the neighbourhoods inhabited by students.

Consuming culture is a regular leisure activity for $65.1 \%$ of students in Turin, although only one in ten students visits a cultural venue at least once per week or more frequently. This type of activity usually takes the form of watching a film in one of the cinemas in the city centre, but visiting museums is also popular. The average monthly cost of cultural consumption is not high (EUR 12.97).

Non-daily shopping is a regular leisure activity for $62.2 \%$ of Turin students, visiting the commercial street, Via Roma (Figure 2 ), or the shopping centres encircling the inner city. Although purchasing non-daily products is the costliest of the leisure activities of Turin youth studied, the average expenditure of EUR 41.92 is relatively balanced compared to the money spent on other purposes.

Turin students should be considered occasional clubbers, since just $41.7 \%$ of them visit music and night clubs once per month or more frequently. Usually, they go to the clubs in the city centre, within walking distance of Via Roma. Regularly visiting clubs is also of moderate cost, as the students who do this report an average expenditure of EUR 19.89 per month.

Practising sports is more frequent than clubbing, even though it requires more money. Almost half of the students surveyed $(48.2 \%)$ regularly visit sports venues, such as gyms, 
MISCELLANEA GEOGRAPHICA - REGIONAL STUDIES ON DEVELOPMENT

Vol. $24 \cdot$ No. 4 • 2020 • pp. 253-262 • ISSN: 2084-6118 • DOI: 10.2478/mgrsd-2020-0023

Table 3. Expenditure on students' leisure activities

\begin{tabular}{|c|c|c|c|c|c|c|}
\hline \multirow{3}{*}{ Activity } & \multicolumn{3}{|c|}{ Lodz } & \multicolumn{3}{|c|}{ Turin } \\
\hline & \multirow{2}{*}{$\mathbf{n}$} & \multicolumn{2}{|c|}{ Expenditure } & \multirow{2}{*}{$\mathbf{n}$} & \multicolumn{2}{|c|}{ Expenditure } \\
\hline & & Mean $\left[E U R^{* *}\right]$ & Median [EUR $\left.{ }^{* *}\right]$ & & Mean [EUR] & Median [EUR] \\
\hline Visiting music \& night clubs & 399 & 16.87 & 11.90 & 416 & 19.89 & 18.75 \\
\hline Visiting pubs and cafés & 801 & 14.85 & 11.90 & 834 & 23.33 & 20.00 \\
\hline Visiting cultural venues & 605 & 9.98 & 7.14 & 654 & 12.97 & 10.00 \\
\hline Visiting sports venues & 549 & 14.21 & 11.90 & 480 & 28.58 & 24.00 \\
\hline $\begin{array}{l}\text { Doing non-daily shopping } \\
\text { (e.g. clothing, electronics) }\end{array}$ & 898 & 40.35 & 23.80 & 602 & 41.92 & 30.00 \\
\hline $\begin{array}{l}\text { Meeting friends at home* } \\
\quad \text { (as a guest or host) }\end{array}$ & 940 & 12.95 & 9.95 & 810 & 9.76 & 0.00 \\
\hline
\end{tabular}

* 'Home' means place of permanent or temporary residence.

${ }^{* *}$ PLN converted to EUR. EUR/PLN rate $=4.20$ (consistent with the survey period).

Source: own elaboration. Values calculated from the answers provided by students declaring they undertook particular types of activities regularly only.

Table 4. Geography of students' leisure activities

\begin{tabular}{|c|c|c|c|c|c|c|c|c|c|c|}
\hline \multirow[b]{3}{*}{ Activity } & \multicolumn{5}{|c|}{ Lodz } & \multicolumn{5}{|c|}{ Turin } \\
\hline & \multirow[b]{2}{*}{$\mathbf{n}$} & \multicolumn{4}{|c|}{ Geography } & \multirow[b]{2}{*}{$\mathbf{n}$} & \multicolumn{4}{|c|}{ Geography } \\
\hline & & $\begin{array}{c}\text { City } \\
\text { centre* }^{*} \\
\%\end{array}$ & $\begin{array}{l}\text { HEI } \\
\text { area }^{* * *} \\
\%\end{array}$ & $\begin{array}{c}\text { Neigh- } \\
\text { bour- } \\
\text { hood }^{\star * * *} \\
\%\end{array}$ & $\begin{array}{c}\text { Another } \\
\text { area } \%\end{array}$ & & $\begin{array}{c}\text { City } \\
\text { centre }^{* *} \\
\%\end{array}$ & $\begin{array}{c}\text { HEI } \\
\text { area*** }^{*} \\
\%\end{array}$ & $\begin{array}{l}\text { Neigh- } \\
\text { bour- } \\
\text { hood**** }^{*} \\
\%\end{array}$ & $\begin{array}{c}\text { Another } \\
\text { area \% }\end{array}$ \\
\hline $\begin{array}{l}\text { Visiting music \& night } \\
\text { clubs }\end{array}$ & 397 & 71.3 & 7.6 & 14.6 & 6.5 & 406 & 53.9 & 8.9 & 13.1 & 24.1 \\
\hline Visiting pubs and cafés & 777 & 68.5 & 12.5 & 13.5 & 5.5 & 791 & 45.5 & 13.8 & 23.3 & 17.4 \\
\hline Visiting cultural venues & 603 & 59.4 & 8.8 & 12.9 & 18.9 & 636 & 63.7 & 6.6 & 10.2 & 19.5 \\
\hline Visiting sports venues & 503 & 23.3 & 12.9 & 40.8 & 23.0 & 444 & 4.7 & 12.4 & 48.0 & 34.9 \\
\hline $\begin{array}{c}\text { Doing non-daily } \\
\text { shopping } \\
\text { (e.g. clothing, electronics) }\end{array}$ & 852 & 38.7 & 8.2 & 38.5 & 14.6 & 582 & 54.3 & 5.5 & 14.4 & 25.8 \\
\hline
\end{tabular}

* 10 minutes' walking distance from Ulica Piotrkowska in Lodz.

** 10 minutes' walking distance from Via Roma in Turin.

*** 10 minutes' walking distance from the student's place of education in Lodz or Turin.

**** 10 minutes' walking distance from the student's place of residence in Lodz or Turin.

Source: own elaboration. Values calculated from the answers provided by students declaring they undertook particular types of activities regularly only.

swimming pools, and sports clubs, although the majority (51.8\%) do so occasionally or not at all. The city's students practise sports most frequently near where they live, spending EUR 28.58 per month on average.

Common and distinctive patterns of students' leisure consumption in Lodz and Turin

The comparison of the images from both cities shows that Lodz students spend less (EUR) than Turin students on leisure on average. This observation was expected due to the differences in price levels in Poland and Italy. However, the comparison also reveals common patterns in each of the three dimensions studied (Table 5), despite the contextual differences of these two student populations and their host cities. First and most importantly, Lodz and Turin students have almost twin hierarchies of leisure activities in terms of their frequency and associated expenditure. The most common leisure activity is meeting friends at home, whether they are hosts or guests. Secondly, students in both cities often meet in pubs and cafés, even though it requires money. Furthermore, the study reveals similar patterns of frequency and relative expenditure associated with visiting cultural venues and music and night clubs. Thirdly, the geographical distribution of students' leisure activities shows that students use particular areas of the respective cities 


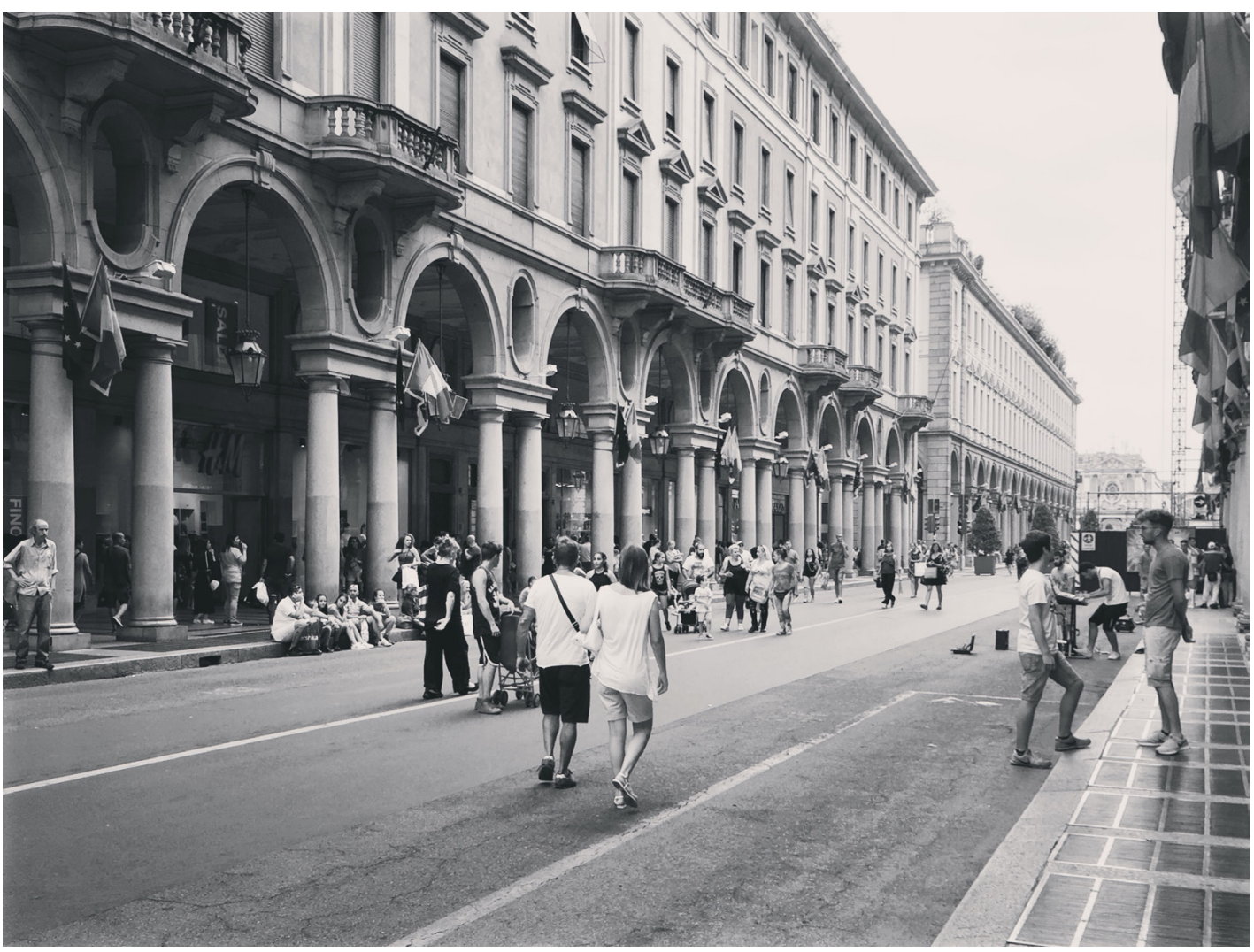

Figure 2. Via Roma in Turin

Source: Jakub Zasina (2017).

for particular purposes in a similar way. From the students perspective, city centres are places to have fun in music and night clubs, pubs and cafés and cultural venues, and to shop (for non-daily products). Meanwhile, the neighbourhoods they inhabit host mostly home meetings and sports activities. The surroundings of the HEI facilities in Lodz and Turin are not, generally speaking, common areas of leisure activities of the students.

Despite the revealed similarities, two outlying and intriguing phenomena require more attention. Firstly, shopping for nondaily products (such as clothing or electronics) is a much more frequent and more economically important leisure activity for students in Lodz than in Turin. On the one hand, it might be a specific pattern for a post-socialist society, in which the ability to consume has become one of the most vivid determinants that influence social strata (Sýkora \& Bouzarovski 2012). On the other, it may be an effect of the rising purchasing power due to the continuous growth of the Polish economy in recent years. However, there are some grounds to think that the very frequent shopping activity declared by Lodz students' does not necessarily mean that they purchase goods very frequently. In post-socialist societies, 'window shopping' in malls is often a way to spend leisure time and to socialise (Cudny 2016). In contrast, the low shopping activity of Turin students might be the result of the austerity of the Italian economy after the 2008 global financial crisis and its consequences, e.g. prolonging economic stagnation and limited job opportunities for the youth (Caruso, Pede \& Rossignolo 2019).

Secondly, the patterns of visiting cultural venues show a preference for more sophisticated activities among Turin students than their counterparts in Lodz. In both cities overall, the popularity of watching films in cinemas is comparable, but only Turin students claim they regularly visit museums. It might be a matter of the good reputation of Turin's museums and their ticketing policy (supply side) or a matter of students' tastes (demand side). Nevertheless, further research into these two phenomena is needed to explain them correctly.

The role of students' leisure consumption for their host cities

In the light of the analysis, university students should be perceived as an important consumer group in contemporary university cities, not just because of the size of their population but also because of the patterns of their leisure activities. The evidence shows that students' leisure time in Lodz and Turin consists of many out-of-home activities associated with purchasing services and goods. Despite the fact that in both cities the single most common activity is meeting friends at home, their venue-based consumption involves much higher expenditure in total. In other words, student lifestyles seem to follow the neoliberal pattern of commodification (Chatterton 2010), as they commonly involve visiting pubs and cafés, as well as visiting cultural and sports venues, or going shopping for nondaily products. Therefore, the student populations seem to be rather 'lucrative' for businesses operating in these two urban economies. This finding is noteworthy, especially from the Polish perspective, where previous research found that students ' $[. .$. stay in, rather than go out and spend money in pubs and bars' (Grabkowska \& Frankowski 2016). By contrast, the results of the research presented here suggest leisure preferences for venuebased consumption. Thus, it might be assumed that, to a certain extent, the presence of students in a university city accelerates its economy through the development of the 'student urban service 
MISCELLANEA GEOGRAPHICA - REGIONAL STUDIES ON DEVELOPMENT

Vol. 24 • No. 4 • 2020 • pp. 253-262 • ISSN: 2084-6118 • DOI: 10.2478/mgrsd-2020-0023

Table 5. Common and distinctive patterns of students' leisure consumption

\begin{tabular}{|c|c|c|}
\hline Lodz distinctive patterns & Lodz and Turin common patterns & Turin distinctive patterns \\
\hline $\begin{array}{l}\text { Doing non-daily shopping (e.g. } \\
\text { for clothing, electronics) is a very } \\
\text { common leisure activity. } \\
\text { - Visiting cultural venues is limited to } \\
\text { watching films in multiplexes. }\end{array}$ & $\begin{array}{l}\text { - } \quad \text { Meeting friends at home is the most } \\
\text { frequent leisure activity. } \\
\text { Mean expenditure on meeting } \\
\text { friends at home is lower than mean } \\
\text { expenditure on other, out-of-home } \\
\text { types of leisure activities. } \\
\text { Visiting music \& night clubs is the least } \\
\text { frequent leisure activity. } \\
\text { - Sports venues are visited very } \\
\text { frequently or not at all. } \\
\text { City centres serve as places for } \\
\text { entertainment in pubs and cafés, } \\
\text { cultural venues and music \& night } \\
\text { clubs, and for shopping. } \\
\text { Students visit sports venues in the } \\
\text { neighbourhoods they inhabit. } \\
\text { Areas next to HEl facilities do not } \\
\text { attract many students for leisure } \\
\text { activities. }\end{array}$ & $\begin{array}{l}\text { - Visiting pubs and cafés is a very } \\
\text { common leisure activity. } \\
\text { Visiting cultural venues is dominated } \\
\text { by watching films in cinemas, but also } \\
\text { includes seeing museum exhibitions. }\end{array}$ \\
\hline
\end{tabular}

Source: own elaboration.

sector', as Chatterton (2010) called it, which includes leisure venues such as pubs, cafés, cinemas, gyms, and clubs.

Nonetheless, the results show that student lifestyles are not as spectacular as they once seemed. Put briefly, much of the prior research on students' leisure practices focused mainly on their nights out (e.g. Hollands 1995; Chatterton 1999; Brands, Schwanen \& van Aalst 2014; Gant \& Terry 2017). Considered in this light, the evidence from Lodz and Turin shows that there are students who do regularly party in music and night clubs, but their number is far smaller than those who prefer other, more 'mundane' types of leisure (such as practising sports or watching films in cinemas). Therefore, student leisure seems to be a complex set of consumer practices that we should be aware of when assessing the role of students as actors of urban change.

A surprising finding of this study is the level of popularity of non-daily shopping (e.g. for clothing or electronics), especially among the students in Lodz. The evidence shows that of the leisure activities analysed, it is not only the second most regular activity for Lodz students, but also the costliest. Therefore, shopping activities seem to be one of the crucial aspects of students' lifestyles and, perhaps, their identities as well. This intriguing finding strengthens the link between the notions of consumerism and the 'student city', but then it also raises questions about the economic consequences of this phenomenon for cities that host HEls and their students. Suffice to say, numerous municipal policies that stress the need to attract students, as well as analyses of the economic impact of HEls on their host communities, suggest that student money acts as a stimulus for local businesses growth (Hermannsson, McGregor \& Swales 2018). However, because the large share of student expenditure on clothing and electronics might be assumed to go to the stores of multinational corporations, the local benefits (multipliers) from students' consumption might prove to be limited. Yet, the more moderate picture of this issue from Turin does not allow for generalisations.

Finally, the research reveals that student populations use particular urban areas for certain leisure activities. The evidence shows that students' entertainment venues (music and night clubs, pubs and cafés, cinemas and museums) and shopping are concentrated in the central areas of Lodz and Turin. In both cities, students do not go out much near the HEI facilities where they study, although some student leisure activities, such as sports, take place in the neighbourhoods where they live. Therefore, it seems that the Polish and Italian students differentiate places of fun from those of accommodation and education, as has been argued in other studies (e.g. Russo \& Tajter 2007; MurzynKupisz \& Szmytkowska 2015; Calvo 2017). In other words, it is the city centres of Lodz and Turin that are undergoing a consumptionoriented restructuring led by the students' demand for leisure and entertainment. In contrast, restructuring of this type seems to be limited in other areas of both cities. However, this spatial distinction between students' leisure, on the one hand, and their places of residence and education, on the other, might be a phenomenon that is unique to large (Russo \& Tajter 2007) or postindustrial cities (Wattis 2013), such as Lodz and Turin.

\section{Conclusions}

This paper focused on the intersection of two essential processes in post-industrial urban restructuring, namely the rise of consumerism and the growth of higher education enrolments, which are taking place worldwide in numerous cities that host university students. It proposed a three-dimensional framework (consisting of the temporal, economic, and spatial dimensions) of studying university students' consumption patterns, and it employed this using quantitative survey data gathered among student populations in Lodz, Poland and Turin, Italy. Attention was paid to students' leisure activities, such as visiting music and night clubs, pubs and cafés, and cultural and sports venues, as well as doing non-daily shopping and meeting friends at home. The analysis aimed to identify students' leisure practices and their role in the cities that host the youth.

As a consequence, the study adds a picture of students' leisure consumption patterns to the flourishing debate on the rise of the 'consumption-oriented student city' and students' role as actors of urban change (Chatterton 2010). First of all, the study comprehensively approached student leisure by analysing a wide range of leisure activities, in contrast to prior research which focused predominantly on students' nights out. Consequently, 
it has revealed that student leisure in Lodz and Turin consists of a heterogeneous set of activities, among which, night-time entertainment in music and night clubs plays a marginal role. Therefore, the evidence from the two cities suggests that the student urban leisure sector should be associated more with pubs, cafés, cinemas and gyms, as well as shops (that sell nondaily products, such as clothing and electronics).

Secondly, this contribution has shown that urban restructuring, led by the rise of consumer culture and the massification of higher education, touches mostly on city centres. More precisely, the majority of Lodz and Turin students' leisure activities take place in consumption venues located in the central areas of both cities and, to a much lesser extent, around the students' places of residence and education. Therefore, students' geographies of leisure in both cities share some similarities with the 'urban playscapes' phenomenon (Chatterton \& Hollands 2002; Crivello 2011). However, get-togethers at home were found to be extremely popular among both sets of students, which supports the recent view that 'more mundane spaces' should also be considered noteworthy consumption geographies for empirical studies (Lane \& Mansvelt 2020).

Thirdly, the formula of comparative research led to the conclusion that despite some differences in the pictures of students' leisure in Lodz and Turin, they share, surprisingly, many similarities. Thus, future research should strive to gauge to what extent contemporary students' leisure consumption patterns are globalised and universal across university towns and cities.

Nevertheless, the research presented has some limitations that could be tackled in the future. Although the value of this contribution is an analysis based on samples reflecting the entire student populations of Lodz and Turin, in contrast to previous papers which focused on particular student cohorts, it does not provide insights into the leisure differences between particular student sub-populations. Therefore, when addressing studenthood diversity (Holton 2019), future research could illuminate the differences in leisure consumption by the students' domicile, residence, level of education, and other characteristics. Furthermore, the focus of this contribution was on students' consumption of leisure, while the production of leisure was not investigated. Thus, questions can also be raised about the degree to which students are not just leisure consumers but also its providers (Chatterton 1999; Boersma, Langen \& Smets 2013). Finally, this paper proposed thinking about the spatial distribution of student leisure activities in a simplified way. Hence, this issue needs further research with better geographical accuracy.

Funding

This research is part of the project financed by the National Science Centre, Poland (NCN), Grant No. 2016/23/N/HS4/03390.

\section{Acknowledgements}

The author would like to thank numerous researchers and students of the University of Lodz and Politecnico di Torino for their support at different stages of this research. He would like to express special thanks to Aleksandra Nowakowska, Marco Santangelo, Elżbieta Antczak, Erica Mangione, Mariusz Sokołowicz, and the reviewers. Any shortcomings regarding the content of the paper fall under the responsibility of the author.

\section{ORCID}

Jakub Zasina (1D https://orcid.org/0000-0001-7519-6982

\section{References}

Ackermann, A \& Visser, G 2016, 'Studentification in Bloemfontein, South Africa', Bulletin of Geography. Socio-economic Series, vol. 31, pp. 7-17.

Allinson, J 2006, 'Over-Educated, Over-Exuberant and Over Here? The Impact of Students on Cities', Planning Practice and Research, vol. 21, no. 1, pp. 79-94.

Boersma, K, Langen, H \& Smets P 2013, 'Paradoxes of Studentification: Social Mix versus Gentrification in a Disadvantaged Neighborhood in Amsterdam East', The Open Urban Studies Journal, vol. 6, pp. 40-49.

Brands, J, Schwanen, T \& van Aalst, I 2014, 'Spatiotemporal variations in nightlife consumption: A comparison of students in two Dutch cities', Applied Geography, vol. 54, no. C, pp. 96-109.

Brockliss, L 2000, '2000 Gown and Town. The University and the City in Europe, 1200-2000', Minerva, vol. 38, pp. 147-170.

Bromley, RDF, Tallon, AR \& Thomas, CJ 2003, 'Disaggregating the Space-Time Layers of City-Centre Activities and Their Users', Environment and Planning A, vol. 35, no. 10, pp. 1831-1851.

Calvo, DM 2017, 'Understanding international students beyond studentification: A new class of transnational urban consumers. The example of Erasmus students in Lisbon (Portugal)', Urban Studies, vol. 40, no. 1.

Calvo, DM, Nofre, J \& Geraldes, M 2017, 'The Erasmus Corner: place-making of a sanitised nightlife spot in the Bairro Alto (Lisbon, Portugal)', Leisure Studies, vol. 36, no. 6, pp. 778792.

Caruso, N, Pede, E \& Rossignolo, C 2019, 'The Reinvention of Turin's Image', disP - The Planning Review, vol. 55, no. 1, pp. 6-17.

Città di Torino 2018, 'Ufficio di Statistica. Dati statistici, indicatori demografici' ['Statistical Office. Statistical data, demography indicators']. Available from: <http://www.comune.torino.it/ statistica/dati/indicat.htm>. [20 June 2018].

Chatterton, P 1999, 'University students and city centres - the formation of exclusive geographies. The case of Bristol, UK', Geoforum, vol. 30, pp. 117-133.

Chatterton, P 2010, 'The Student City: An Ongoing Story of Neoliberalism, Gentrification, and Commodification', Environment and Planning A, vol. 42, no. 3, pp. 509-514.

Chatterton, P \& Hollands, RG 2002, 'Theorising Urban Playscapes: Producing, Regulating and Consuming Youthful Nightlife City Spaces', Urban Studies, vol. 39, no. 1, pp. 95-116.

Christie, H, Munro, M \& Rettig, H 2001, 'Making Ends Meet: student incomes and debt', Studies in Higher Education, vol. 26 , no. 3, pp. 363-383.

Clark, TN 2011, 'Introduction: Taking Entertainment Seriously' in The City as an Entertainment Machine, ed TN Clark, Lexington Books, Plymouth, pp. 1-14.

Collins, FL 2010, 'International students as urban agents: International education and urban transformation in Auckland, New Zealand', Geoforum, vol. 41, no. 6, pp. 940-950.

Crivello, S 2011, 'Spatial dynamics in the urban playscape: Turin by night', Town Planning Review, vol. 82, no. 6, pp. 709-731.

Cudny, W 2016, 'Manufaktura in Łódź, Poland: An example of a festival marketplace', Norsk Geografisk Tidsskrift - Norwegian Journal of Geography, vol. 70, no. 5, pp. 276-291.

Daniłowicz, P 2007, 'Problemy badań i analiz porównawczych. Zarys problematyki' ['Comparative studies and analyses. 
The scale of a problem'], Przegląd Socjologiczny, vol. 1, pp. 221-243.

Dubet, F 2006, 'Young People and Students' in City and university. University cities and urban campuses, eds C Bellet \& J Ganau, Editorial Milenio, Lleida, pp. 85-105.

Fabula, S, Boros, L, Kovács, Z, Horváth, D \& Pál, V 2017, 'Studentification, diversity and social cohesion in postsocialist Budapest', Hungarian Geographical Bulletin, vol. 66 , no. 2, pp. 157-173.

Gaczek WM \& Kaczmarek M 2015 Poznański ośrodek akademicki. Zachowania konsumenckie studentów [Poznań as an academic centre. Consumer behaviour of students], Bogucki Wydawnictwo Naukowe, Poznań.

Gant, R \& Terry, P 2017, 'Narrative of the night-out: Student engagement in the night-time economy of Kingston upon Thames', Local Economy, vol. 32, no. 5, pp. 467-481.

Gałuszka, J 2017, 'Examining patterns of policy change in a post-socialist city: the evolution of inner-city regeneration approaches in Łódź, Poland, after 1989', Town Planning Review, vol. 88, no. 6, pp. 639-664.

Garmendia, M, Coronado, JM \& Ureña, JM 2012, 'University Students Sharing Flats: When Studentification Becomes Vertical', Urban Studies, vol. 49, no. 12, pp. 2651-2668.

Grabkowska, M \& Frankowski, J 2016, "'Close to the city centre, close to the university". Are there symptoms of studentification in Gdańsk, Poland?', Bulletin of Geography. Socio-economic Series, vol. 32, pp. 73-83.

Hauschildt, K, Gwosć, C, Netz, N \& Mishra, S 2015, Social and Economic Conditions of Student Life in Europe, W. Bertelsmann Verlag GmbH \& Co. KG, Bielefeld.

Hermannsson, K, McGregor, PG \& Swales, JK 2018, 'Students' consumption expenditures in economic impact studies: assumptions revisited in an input-output approach for Scotland', Regional Studies, Regional Science, vol. 5, no. 1, pp. 57-77.

Hollands, RG 1995, Friday Night, Saturday Night: Youth Cultural Identification in The Post-Industrial City, Department of Social Policy, University of Newcastle upon Tyne, Newcastle upon Tyne.

Holton, M 2019, 'Debating the geographies of contemporary higher education students: diversity, resilience, resistance?', Children's Geographies, vol. 17, no. 1, pp. 13-16.

Jayne, M 2006, Cities and Consumption, Routledge, Abingdon.

Kotus, J, Rzeszewski, M \& Bajerski, A 2018, Visitors in Urban Structures. Students and Tourists in the City, OpenGeoHum, Poznań.

Lane, R \& Mansvelt, J 2020, 'New consumption geographies: Introduction to the special section', Geographical Research, Ahead from print. Available from: <https://onlinelibrary.wiley. com/doi/abs/10.1111/1745-5871.12410>

Mangione, E 2019, 'Le politiche per la città universitaria: esiti e trasformazioni a Torino' ['Which policies for the university city: outcomes and transformations in Turin'], Atti e Rassegna Tecnica della Società degli Ingegneri e degli Architetti in Torino, vol. LXXIII, no. 2, pp. 161-167.

Moos, M, Revington, N, Wilkin, T \& Andrey, J 2019, 'The knowledge economy city: Gentrification, studentification and youthification, and their connections to universities', Urban Studies, vol. 56, no. 6, pp. 1075-1092.

Munro, M \& Livingston, M 2012, 'Student Impacts on Urban Neighbourhoods: Policy Approaches, Discourses and Dilemmas', Urban Studies, vol. 49, no. 8, pp. 1679-1694.

Murzyn-Kupisz, M \& Szmytkowska, M 2015, 'Studentification in The Post-Socialist Context: The Case of Cracow and The Tri-City (Gdansk, Gdynia and Sopot)', Geografie, vol. 120, no. 2, pp. 188-209.
Nakazawa, T 2017, 'Expanding the scope of studentification studies', Geography Compass, vol. 11, no. 1, e12300.

Oldenburg, R 1999, The Great Good Place: Cafes, Coffee Shops, Bookstores, Bars, Hair Salons, and Other Hangouts at the Heart of a Community, 3rd edn, Da Capo Press, Cambridge MA.

OSSREG 2017, 'Il sistema universitario. Dati statistici e di confronto' ['The university system. Statistical and comparative data']. Available from: <http://www.ossreg piemonte.it/default_it.asp>. [15 November 2017].

Ponzini, D \& Santangelo, M 2018, 'Spatial strategies through land-use plans, urban projects and metropolitan visions: twenty-five years of planning in Turin', Town Planning Review, vol. 89, no. 3, pp. 259-282.

Robinson, J 2017, 'Comparison' in Urban Theory. New Critical Perspectives, eds. M Jayne \& K Ward, Routledge, London \& New York, pp. 84-98.

Russo, AP \& Tajter, LC 2007, 'From Citadels of Education to Cartier Latins (and Back?): The Changing Landscapes of Student Populations in European Cities', Geography Compass, vol. 1, no. 5, pp. 1160-1189.

Ruming, K \& Dowling, R 2017, 'PhD students' housing experiences in suburban Sydney, Australia', Journal of Housing and the Built Environment, vol. 32, pp. 805-825.

Sage, J, Smith, DP \& Hubbard, P 2012, 'The Diverse Geographies of Studentification: Living Alongside People Not Like Us', Housing Studies, vol. 27, no. 8, pp. 1057-1078.

Skelton, T \& Gough, KV 2013, 'Introduction: Young People's Im/ Mobile Urban Geographies', Urban Studies, vol. 50, no. 3, pp. 455-466.

Smith, DP 2005, "'Studentification ication": the gentrification factory?' in Gentrification in a global context: the new urban colonialism, eds R Atkinson \& G Bridge, London, pp. 73-90.

Smith, DP \& Holt, L 2007, 'Studentification and "apprentice" gentrifiers within Britain's provincial towns and cities: extending the meaning of gentrification', Environment and Planning A, vol. 39, no. 1, pp. 142-161.

Smith, DP \& Hubbard, P 2014, 'The segregation of educated youth and dynamic geographies of studentification', Area, vol. 46, no. 1, pp. 92-100.

Sokołowicz, ME 2019, 'Student cities or cities of graduates? The case of Lodz and its students declared preferences', Population, Space and Place, vol. 25, no. 2, e2177.

Statistics Poland 2018, 'Local Data Bank'. Available from: <https://bdl.stat.gov.pl/BDL/start>. [20 June 2018].

Steinacker, A 2005, 'The economic effect of urban colleges on their surrounding communities', Urban Studies, vol. 42, no. 7, pp. 1161-1175.

Sýkora, L \& Bouzarovski, S 2012, 'Multiple Transformations: Conceptualising the Post-communist Urban Transition', Urban Studies, vol. 49, no. 1, pp. 43-60.

Wattis, L 2013, 'Class, Students and Place: Encountering Locality in a Post-industrial Landscape', Urban Studies, vol. 50, no. 12 , pp. $2425-2440$.

Zasina, J 2020, Student cities - Consumer cities. Students' consumption and the development of Lodz and Turin, Wydawnictwo Uniwersytetu Łódzkiego, Łódź.

Zasina, J, Sokołowicz, ME \& Nogalski, S 2020, 'Lodz City Tour. The Changing Nature of the Urban Restructuring of a PostSocialist Industrial City', disP - The Planning Review, vol 56, no. 2, pp. 8-19

Zysiak, A2016. Punkty za pochodzenie. Powojenna modernizacja $i$ uniwersytet $w$ robotniczym mieście [Points for class origin. Postwar modernization and the university in a working-class city], NOMOS, Kraków. 